
завідувач кафедри вокалу та диригентсько-хорових дисциплін Хмельнииької гуманітарно-педагогічної академії (Хмельницький, Україна) tsarsvit@ukr.net

\title{
Росіна ГУЦАЛ,
} orcid.org/0000-0002-9343-9690 кандидат мистецтвознавства, доиент кафедри вокалу та диригентсько-хорових дисциплін Хмельницької гуманітарно-педагогічної академії (Хмельницький, Україна) rosina_r@ukr.net

\section{AРТИСТИЧНИЙ БУКЕТ ТЕНОРА DI GRAZIA ОЛЕКСАНДРА ФІЛІППІ-МИШУГИ}

\begin{abstract}
Життевий шлях видатних діячів для історії кожної нації важливий як свого роду символ иілого народу, підтвердження певного етапу його історичного розвитку, свідчення його духовного потенціалу. Щодо ряду видатних письменників і поетів, це твердження вже апробовано у філософській, культурологічній та сочіологічній літературі. Натомість складніше і більш опосередковано визначаються подібні взаємозв'язки у інших видів мистецтва, головно в музиці. Тут здебільшого стверджується вагома роль композиторів та виконавців у становленні культурних інституиій та збереженні духовних традицій.

Але насправді видатні виконавці - співаки й інструменталісти - теж посідають у цьому багатогранному процесі важливе місие. Нерідко діяльність того чи іншого музиканта-виконавия завдяки його безпосередній спрямованості на аудиторію, а відтак - виняткової чутливості до соиіальних імпульсів показує вектори не лише культурно-мистецького, але й політичного та економічного розвитку. Значною мірою ие стосується життєтворчості відомого украӥнського оперного співака Олександра Філіппі-Мишуги (1853-1922 рр.).

Протягом всієї своєї співочої кар'єри Мишуга поєднував кілька родів діяльності, однаково ангажуючись не лише в оперні виступи, але й в камерне концертне музикування, педагогіку та суспільну працю. Різні прояви і виміри мала і суспільно-харитативна діяльність О. Мишуги - від фінансової підтримки потребуючих до пожертв на культурно-мистецькі, освітні, просвітницькі иілі, зрештою, до опіки і турботи про талановитих учнів, які не лише навчались безоплатно у видатного професора, але й нерідко користувались його матеріальною допомогою. Це свідчить і про особливу громадянську позицію видатного артиста у час становлення і професіоналізації українського музичного мистецтвва.

Його творча, вокально-педагогічна та просвітницька діяльність відбувалася під безпосереднім впливом ідей, які утверджувалися наприкінці XIX - на початку XX cm. на украӥнських землях і були тісно пов'язані з утвердженням національної свідомості і професіоналізаџією мистецького життя, відтак - піднесенням мистецького рівня в найрозмаӥтіших галузях, передусім в кониертно-виконавській та музично-освітній площині.
\end{abstract}

Ключові слова: Олександр Мишуга, Філіппі-Мишуга, вокально-виконавська діяльність, співак, ліричний тенор, українська вокальна школа. 
Svitlana TSARUK, orcid.org/0000-0002-1493-4977

Candidate of Art Criticism, Associate Professor, Head of the Department of Vocal and Conductor-Choral Disciplines Khmelnytskyi Humanitarian-Pedagogical Academy (Khmelnytskyi,Ukraine) tsarsvit@ukr.net

\author{
Rosina HUTSAL, \\ orcid.org/0000-0002-9343-9690 \\ Candidate of Art Criticism, \\ Associate Professor at the Department of Vocal and Conductor-Choral Disciplines \\ Khmelnytskyi Humanitarian-Pedagogical Academy \\ (Khmelnytskyi,Ukraine) rosina_r@ukr.net
}

\title{
ARTISTIC BOUQUET OF TENOR DI GRAZIA ALEXANDER PHILIPPY MYSHUGA
}

The life path of outstanding figures for every nation's history is important as its symbol, confirmation of a certain historical development stage, the evidence of its spiritual potential. In relation to a number of prominent writers and poets, this statement has already been analyzed in philosophical, culturological and sociological literature. However, similar relationships in other arts, mainly in music, are identified more difficult and indirect. In this case, the emphasis is on the important role of composers and performers in the formation of cultural institutions and the preservation of spiritual traditions.

But in fact, outstanding performers - singers and instrumentalists - also play an important role in this multifaceted process. Often the activity of a musician-performer due to his/her direct focus on the audience, and hence, exceptional sensitivity to social impulses shows the vectors of not only cultural and artistic, but also political and economic development. To a large extent, this applies to the life of the famous Ukrainian opera singer, actor, prominent teacher and active public figure Oleksandr Filippi-Myshuga (1853-1922).

Throughout his singing career, Myshuga has combined several activities, equally engaged not only in opera performances, but also in chamber concert music, pedagogy and social work. O. Myshuga's social and charitable activities had various manifestations and dimensions, from financial support to the needy to donations for cultural, artistic, educational, educational purposes, and finally, to the care of talented students who not only studied for free with an outstanding professor, but often used his material assistance. This testifies to the special outstanding artist's civic position during the formation and professionalization of Ukrainian musical art.

His creative, vocal-pedagogical and educational activities took place under the direct influence of ideas that were established in the late nineteenth - early twentieth century in the Ukrainian lands and were closely connected with the establishment of national consciousness and professionalization of artistic life, and thus - the rise of the artistic level in various fields, especially on concert-performing and music educational levels.

Key words: Oleksandr Myshuga, Filippi-Myshuga, vocal-performing activity, singer, lyrical tenor, Ukrainian vocal school.

Постановка проблеми. Незважаючи на доволі об'ємний компендіум літератури - i мемуарної, і біографістики, і наукової, і відгуків преси, повністю «реконструювати» етапи становлення творчої особистості Олександра Мишуги не видавалося можливим. У суб'єктивних джерелах - автобіографії, спогадах-розповіді близьким людям - надзвичайно важливим моментом видається емоційно-психологічна інтерпретація подій, яка підтверджує характеристики особистості видатного співака, завдяки яким він досягнув вершин мистецької майстерності. Об'єктивна ж інформація - існуючі наукові й популярні розвідки, пресові та архівні матеріали - дозволяють докладно простежити життєвий шлях співака світової слави, педагога, громадського діяча Олександра Філіппі-Мишуги. Саме через зіставлення об’єктивної та суб’єктивної інформації отри- муємо повний і переконливо задокументований перебіг його життєвих подій.

Аналіз досліджень. Велика кількість спогадів відомих діячів вітчизняної культури та зарубіжних країн про митця міститься у праці дослідника Івана Деркача «Видатний співак Олександр Мишуга. Спогади» (1964р.). Пізніше, 1971 р., знавець творчості співака Михайло Головащенко видає книгу «Олександр Мишуга. Спогади. Матеріали. Листи», яка, окрім спогадів сучасників, містить листи, архівні документи і літературні твори, присвячені співаку, педагогу, громадському діячу. Друге видання матеріалів про знаного українця «Олександр Мишуга - король тенорів» М. Головащенка вийшло друком 2004 р..

Документальною основою статті стали матеріали Центрального державного історичного архіву України (м. Львів), бібліотеки Варшавського 
музичного університету ім. Ф. Шопена, Національної бібліотеки Польщі (м. Варшава), публікації з досліджуваної проблематики; матеріали польської та української преси, енциклопедичні та довідкові видання, спогади, які, разом з архівними документами, стали джерелом важливих відомостей.

Метою статті $\epsilon$ аналіз основних віх творчого становлення, оперної кар'єри О. Філіппі-Мишуги на основі автобіографічних, пресових, архівних матеріалів, наукових розвідок, присвячених співакові, визначені його основні світоглядні позиції.

Виклад основного матеріалу. «Олександр Мишуга зарекомендував себе блискучим представником італійської школи бельканто, особливості якої він зумів поєднати з чисто українською задушевністю. Він підкоряв слухачів досконалістю співу, чіткою дикцією, виразним фразуванням, чудовою кантиленою і майстерною грою. Спів і гра Олександра Мишуги викликали захоплення, подив. Це був справжній поет пісні», писав про видатного українського співака відомий мистецтвознавець Михайло Головащенко (Головащенко, 1971).

Пророкуючи блискучу кар“єру своєму учневі, професор В.Висоцький давав високу оцінку його обдарованості: «Він $є$ тенором di grazia (з італ. благодатний), до якого усміхаються Ельвіни, Неморіни, Ліонели, та навіть Едгари і Фаусти; ці герої чи їм подібні повинні присягнути йому на довічну приязнь, якщо не хочуть, щоби Ернани або інші італійські бандити зі школи Верді зруйнували прекрасну кар'єру, котра на нього чекає. У своєму звучному і проникаючому до глибини душі голосі він володіє багатьма цінними прикметами; впевненість у атаці високих тонів, делікатне mezza voce і легкість в переході від forte до pianissimo дають йому змогу здобувати різноманітні ефекти, яких тільки може вимагати лірична музика. Ці прикмети підсилює ясна і виразна декламація кожного слова, умова дуже важлива, на жаль занедбана багатьма співаками» (Śledziński, 1973).

Уперше талановитий молодий співак вийшов на сцену Львівського театру Скарбека у ролі Стефана, виконавши уривки зі «Страшного двору» Ст. Монюшка. Відомий музичний критик Юзеф Рейсс датою цієї подіїназиває 1879 рік, уточнюючи, що на доленосному для співака спектаклі був присутній цісар Франц Йосиф. (У «Біографічному словнику Польського театру» вказано 13 вересня 1880 р.).

Упродовж 1880-1881 рр. співав у концертах на зразок того, що відбувся 2 березня 1881 року у Великому залі Народного дому. Концерт було присвячено 20-річчю $з$ дня смерті Тараса Шев- ченка. Пізніше впродовж усього життя Олександр Мишуга був частим гостем таких концертів. Нерідко спеціально приїздив до Львова, Києва, щоби заспівати вокальні твори на слова Кобзаря.

У квітні-травні 1881 р. мистецькою громадою Львова було організовано ряд концертів для збору коштів для продовження навчання талановитого молодого співака у Італії. Зібравши достатню для подорожі суму, Мишуга виїхав до Італії. Переживши розчарування, поборовши, здавалося б, нездоланні труднощі, у грудні 1882 року Олександр Мишуга співав у місті Форлі в опері «Марта», як пише сам співак, «з дуже гарним успіхом». Періодична преса не залишила непоміченим виступ артиста Філіппі - сценічне ім'я О. Мишуги. Сам співак дає досить цікаве пояснення його виникнення: «Раз я вичитав фразу "Alexander Magnus, rex Macedoniae, filius Philippi fuit» (Олександр Великий, король Македонії, був сином Філіппа) - ну тай я син Пилипа. От я собі взяв на пам'ять мого батька його ім'я і перемінив на прізвище артистичне, тільки написане по-італійськи Filippi».

Молодий співак Алесандро Філіппі переїздить 3 Форлі до Туріна. За підрахунками М. Варварцева, впродовж 1883 року він брав участь у 31 виставі. Зокрема, співав 12 разів у опері «Любовний напій» Г. Доніцетті, 8 - «Вихованки Соренто» Е. Узільо, 6 - «Сомнамбула» В. Белліні, 5 - «Дядько Мартін» А. Каньоні. Італійські мистецькі періодичні видання, окрім захоплених відгуків на зразок: «Молодий тенор синьйор Філіппі, який має приємний та оброблений голос, у багатьох місцях здобував оплески» та «проявив себе здібним співаком, обдарованим чудовим голосом і талантом», час від часу давали поради та рекомендації, як-от: «Ми рекомендуємо йому виявити себе трохи більш пристрасним» або «Він має симпатичний голос, який, проте, ще потребує багато праці» (Варварцев, 1992).

Микола Варварцев, вивчивши італійські друковані джерела щодо періоду становлення українського співака в Італії, дає йому таку характеристику: «Людина виняткової працьовитості i почуття високої відповідальності, він, за свідченням сучасників, уважно прислухався до думки фахівців, наполегливо шліфував свій голос й манеру гри на сцені протягом усього творчого життя» (Варварцев, 1992).

У вересні 1883 року Мишуга повернувся до Львова, уклавши контракт 3 театром Скарбка. У сезоні 1883/1884 p.p. за його участю йшли опери: «Фауст» Шарля Гуно, «Фаворитка» та «Лючія ді Ляммермур» Гаетано Доніцетті, «Галька» Станіслава Монюшка, а також «Марта» Фрідріха 
Флотова (Паламарчук О., 2007). У цей період С. Пепловські писав про Мишугу: «Зачаровував усіх феноменальним голосом» (Śledziński, 1973).

У Варшавській опері співак вперше виступив 28 квітня 1884 року в ролі Стефана (С.Монюшко «Страшний двір»), як згадує Болеслав Прус, «відразу ж здобув загальне визнання як за голос, так і за артистичний талант» (Головащенко М., 2004). Одразу ж заключив контракт з дирекцією театру і працював у Варшаві до 1891 року. 3 великим успіхом виступав у наступних спектаклях: «Любовний напій» та «Фаворитка» Г. Доніцетті, «Манон» Ж. Массне, «Трубадур» і «Травіата» Дж. Верді, «Фауст» і «Ромео і Джульєтта» Ш. Гуно, «Лунатичка» В. Белліні, «Страшний двір», «Галька» Ст. Монюшка, «Сільська честь» П. Масканьї, «Барбара Радзивілл» Ярецького.

Партнером Мишуги по сцені, зокрема, у «Лунатичці» була Елла Рассел. Музичний критик часопису «Ехо музичне, театральне і артистичне» (1890р.) писав, що виконавці ролей Аміни та Едвіна «є добрими співаками, що уміють передати характер героїв і технічно відповідають вимогам композитора», додаючи про Мишугу: «Співає зі щирими почуттями і смаком» (ЕМТА, 1890).

Відомий польський критик Юзеф Рейсс стверджував, що Олександр Мишуга був «найпрекраснішим ліричним тенором, а також найбільшою гордістю львівської і варшавських сцен в 1880-1900-х роках». Досконале виконання вокальних партій доповнювалось наявністю величезного акторського таланту у співака. Його Альфред із «Травіати» «насправді кохає, впадає у розпач, шаленіє», а у «Ромео і Джульєтті» «в останньому акті піднявся на вершину драматизму, зворушивши аудиторію повними болю та жалю акцентами» (Головащенко, 2004).

Найбільш шанованою слухачами була роль Йонтека, виконувана Мишугою з особливою простотою і винятковим ліризмом. У Ю. Рейсса знаходимо твердження, яке досить часто звучить у різних джерелах про те, що «Мишуга був ідеальним виконавцем тенорових партій у операх Монюшка. Хто не чув арії Йонтека «Szumią jodły na gór szczycie» у його інтерпретації або арії Стефана «Matko moja miła», той не може собі уявити чогось більш жалісливого і більш зворушливого. То був насправді «сердечний спів», що солодкістю і рівністю голосу здатний був викликати сльози у слухачів» (Reiss, 1948).

У характеристиці «першого тенора Великого театру у Варшаві» зазначено: «Велика школа..., правильний метод і постановка голосу, справжнє бельканто, яке останнім часом перестали культивувати, точність і краса музичної фрази, сценічна привабливість - все це зібрано в одній людині, творить справжній артистичний букет прославленого Мишуги. ... в цих трьох сезонах п. ФіліппіМишуга виступив понад 300 разів, а публіка вимагала більше. Кожна любима арія виконувалась на «біс», причому багаторазово» (Головащенко, 2004).

Про краківські тріумфи співака (1885-1890 р.p.) Ю.Рейсс писав, що виступав він «... досить часто, складаючи своє мистецтво у жертву благородній справі: співав на прекрасних вечорах, присвячених Міцкевичу, які влаштовувала в театрі університетська молодь, співав на концертах академічного хору і був, безумовно, найбільшою сенсацією: чарував завжди «тим самим теплом і силою і тим самим майстерним викінченням у найдрібніших деталях» як виконавець польських пісень» (Головащенко, 2004). Тут слід додати, що у польській пресі досить часто Мишугу називали поляком. У львівських газетах час від часу 3'являлись публікації з вимогами прояснити ситуацію, зважаючи на те, що його «народила і виховала собі на пожиток земля руська». I хоча український тенор «під час гостинних виступів у Варшаві дуже там подобався», це ще не привід називати його «nasz rodak» (наш земляк - С. Ц.) (Діло, 1885).

Серед постановок у Кракові, як твердить критика, найбільший успіх мала «Галька» Ст. Монюшка. I знову глядачі аплодували Йонтеку-Мишузі 24 липня 1887 р.. А 1895 року музичний критик Ф. Биліцький помістив у газеті «Час» характеристику одного із виступів на краківській сцені Стефана-Мишуги та двох учениць маестро. Про успіх спектаклю писав: «Ніколи ще не чули ми злагоджених і таких гарячих аплодисментів в театрі, як на виставі «Страшного двору». Оминаючи захоплення, яке завжди викликає Мишуга, котрого зазвичай осипають вінками, букетами i змушують до повторення - гарячі оплески отримали п.п. Срьомін, Гурськи, пані Каспровичівна, панни Королевичівна і Штрассерівна, як рівно хори та оркестр. Публіка, задоволена і оновлена несподівано чудовою виставою, дістала вочевидь переконання, що маємо оперу!» (Bylicki, 1895).

3 гостинними виступами 1885 року Олександр Мишуга виїздив і до Відня. Не можемо залишити поза увагою цікавий факт: контрактом було обумовлене виконання партій виключно німецькою мовою. Проте, блискучий успіх перших двох спектаклів за участі співака («Фаворитка» і «Лючія де Ламмермур») заставив дирекцію театру піти назустріч Мишузі, дозволивши у наступних постановках співати італійською мовою. За твердженням музичних критиків, випадок це був безпрецедентний. 
Львівська газета «Діло» так висвітлювала початок гастрольного туру 1885 року: «Перший його виступ мав надзвичайний успіх. По виконанні кожної арії не вщухали голосні аплодисменти, а артист декілька разів змушений був виходити до публіки, яка не знаходила достатньо сил, щоби виказати йому своє захоплення» (Діло, 1885). По декількох виступах дирекція Віденської опери запросила О. Філіппі-Мишугу до подальшої співпраці, запропонувавши йому виконання провідних ролей у «Ріголетто» і «Травіаті» Дж. Верді: «Факт, що Мишугу заангажовано до подальших виступів, доводить, що він зуміє відповісти вимогам, які ставить така первостепенна сцена світова як віденська опера придворна...» (Діло, 1885).

Впродовж липня 1887 року О. Мишуга співав у Празі в таких спектаклях: «Трубадур» Дж. Верді, «Фауст» Ш. Гуно, «Кармен» Ж. Бізе. Газета «Prager Abendblatt» називала його «видатним співаком-художником», а про виконання ним однієї із арій з опери «Фауст» писала: «В цю вигідну арію чудовий співак вклав (це було всім ясно!) весь свій хист і показав у ній таку багату різноманітність нюансів і відтінків, від найніжнішого pianissimo до могутнього fortissimo, таке вміле і сповнене художнього смаку використання всіх досягнень чудової школи i таку теплоту i щирість слова, що його виступ можна вважати за справжній шедевр бельканто». Анонсуючи передостанній у сезоні виступ співака, газета «Narodni Listy» підводить своєрідний підсумок: «вся критика одностайно визнає Філіппі і ставить його в ряд 3 найкращими оперними співаками взагалі» (Головащенко, 2004).

У 1890 році О.Мишуга багато гастролював. Такі міста як Лодзь, Радом, Сопот мали за честь приймати у себе відомого у Європі тенора. Зокрема, у м. Лодзь Філіппі-Мишуга приїздив зі знаменитою американською співачкою Еллою Рассел. «Пара знаних співаків» з успіхом відспівала «Травіату» і «Ріголетто» Дж. Верді (DTP. TP, 1987). Якийсь час О. Мишуга перебував у Парижі (1887 р.).

Обставини склались таким чином, що 1891 співак змушений був покинути Варшаву. У сезонах 1892/1893, 1893/1894, 1894/1895 р.p. на сцені Львівського театру Скарбека Олександр Мишуга виступав разом із Соломією Крушельницькою. За участі співаків йшли вистави: «Фаворитка» Г. Доніцетті, «Фауст» Ш. Гуно, «Аїда» Дж. Верді, «Галька» та «Страшний двір» Ст Монюшко, «Манон Лєско» Дж. Пуччіні, «Кармен» Ж. Бізе. Варто відзначити, що дебютний виступ С.Крушельницької припав на 15 квітня 1893 року. Разом з О. Мишугою співали «Фаворитку» Г. Доніцетті.
Впродовж вказаних років О. Мишуга та С. Крушельницька багато виступали у концертах, виконуючи твори українських композиторів. До прикладу, у червні 1893 року в Тернополі у залі польського товариства «Сокіл» відбувся їхній концерт, кошти від якого було передано на будівництво «Руської бурси» (ЦДІА м. Львів).

Про виступ співаків 3 березня 1895 року читаємо у Гната Хоткевича: «... С. Крушельницька співала 3 Мишугою на концерті, влаштованім товариством ремісників «Зоря». Відспівали дует з опери «Різдвяна ніч» (М. Лисенка - С.Ц.) та «Запорожця за Дунаєм» (С. Гулака-Артемовського - С.Ц.)». Далі Хоткевич подає цитату із «Галичанина» про те, що виконавці «викликали серед слухачів натхнення, вираженням якого була буря оплесків. Зайвим було б давати детальну оцінку співу тієї опери артистами. Пан Мишуга користується вже здавна славою одного із видатних співаків тенорів в Європі, п. Крушельницька лише недавно сягнула ті лаври...» (ЦДІА м. Львів).

Композитор Денис Січинський про майстерність артистів писав: «Злишнім хіба було би розписуватися о чаруючім співі тої артистичної пари, на се не знайдеться слів, котрими далось би достаточно віддавати враження, якого дізнався, слухаючи їх співу: то ж не буду довго розводитися, а скажу лише, що по кожнім з тих дуетів не було оплескам кінця, і наші артисти мусили вдруге співати». Українські співаки брали участь також у концертах, присвячених роковинам 3 дня смерті Тараса Шевченка 16 травня 1895 року та в березні 1897 року в залі Народного дому у Львові. На першому концерті голова товариства «Боян» та диригент «при ентузіястичних оплесках публіки» піднесли співакам лаврові вінки (Медведик, Мисько-Пасічник, 2008).

Не обмежуючи себе постійним ангажементом, у березні-квітні 1892 року Олександр Мишуга 3 гостинними виступами відвідав Париж, 1900рокуПрагу, Краків і Люблін, 1901 року співав у Варшаві, Вроцлаві, Седлеці, Сосновці, Честохові, 1902 року знову виступав у Варшаві, Лодзі і Закопане.

На сцені Київського міського театру Олександр Мишуга вперше співав 1895 року в межах гастрольного туру. Видатний український хоровий диригент і композитор Олександр Кошиць, описуючи свої враження від виступів українського тенора в ролі Фауста та Йонтека, давав йому таку характеристику: «Здібність знайти найвищу, кульмінаційну точку твору, не тільки музичну, але й психологічну, знати, де покласти шпиль над усією артистичною будовою - це великий дар чуття музичної архітектури, чуття форми і мистецької пропорції! Мишуга 
не лише робив це в окремих ментах мистецького захоплення, ні, це був метод його мистецького творення, починаючи від великої опери і кінчаючи найдрібнішою річчю, яку він виконував. Через те від його виконання крім суцільності залишались не тільки чисто музичні і вокальні враження, але і враження іншого, глибшого порядку, де приходиться вживати термінів психології, філософії і математики. I цікаво, що усі ці успіхи він осягав найбільше й головно самим звуком з його динамічними якостями!» (Головащенко, 2004).

Знову співав у Києві в листопаді 1898 року. На святкуванні 100-літнього ювілею «Енеїди» I. Котляревського виступав «вже відомий тоді оперний співак Олександр Пилипович Мишуга 3 цілим рядом чудових творів, захоплено зустрінутих усіма в залі. Особливо збереглося в пам'яті виконання співаком Шевченкового вірша «Огні горять» у музичному оформлені М. Лисенка», ділився своїми спогадами відомий український письменник Євген Кротевич. (Кротевич, 1963).

О. Мишуга дістав запрошення від дирекції Варшавської опери на сезон 1897/1898. До слова, саме на цей період припадають дебютні виступи двох його учениць: Яніни Королевич-Вайдової і Євгенії Штрассерн. У постановці опери «Лунатичка» разом з Мишугою у ролі Аміни співала Я. Королевич-Вайдова. Музичний критик М. Бернацький відзначив, що у неї «свіжа, тепла барва голосу, інтонація бездоганна, гарна вимова, почуття логічного наголосу і фрази, словом - талант». За два дні потому, вперше на сцені оперного театру Євгенія Штрассерн виступила в ролі Гальки. Критика оцінила іiі прекрасний голос, хоча й зауважила дещо надмірну драматизацію образу. Щодо О. Мишуги, то, підкреслюючи «чудові барви його голосу і тепле звучання у поєднанні з досконалою технікою» у «Травіаті», «Фаусті», «Ромео і Джульєтті», «Лунатичці», «Сільській честі», «Страшному дворі», «Гальці», наголошувалось на тому, що зали, у яких виступав співак, завжди були переповнені.

Отож, дирекція Великого театру уклала угоду 3 Я. Королевич-Вайдовою, Є. Штрассерн, О. Мишугою і на наступний сезон 1898/1899, який виявився не менш вдалим. «Мишуга мав винятковий успіх як Стефан у «Страшному дворі», де «чарував аудиторію шляхетним звучанням голосу i викликав щирий інтерес чуттєвим співом, щирим та витонченим, у фразуванні та артистичній формі» (DTP. 1890-1918, 1988).

1 січня 1899 року відбулась знаменна для шанувальників творчості Станіслава Монюшка подія 40-річний ювілей опери «Галька» (453 постановка). У вечірній постановці роль Гальки виконувала
Євгенія Штрассерн, роль Йонтека - Олександр Мишуга, якого варшавська публіка цінувала за задушевний спів з «винятковим ліризмом» (DTP. 1890-1918, 1988). Критика, в свою чергу, називала його: «безперечно найкращим 3 сучасних виконавців ролі Йонтека». Пізніше, 1912 року для виконання цієї ролі у ювілейній 700-тій постановці оперного спектаклю у Варшавській опері знову було запрошено Олександра Мишугу.

1899 року та 1902 року співав у концерті «Музичного товариства» у Кракові пісні В. Желенського. «Сам композитор постійно акомпанував йому і для нього написав свою «Серенаду». Але ніхто, мабуть, не заспіває так чудово, як Мишуга, «Розчарування» Желенського, ніхто також не буде кращим виконавцем титулової партії в опері «Янек», прем’єра якої відбулася в Кракові в 1901 році», - писав у спогадах Ю. Рейсс (Головащенко, 2004).

Оперою «Янек» В. Желенського було відзначено урочисте відкриття оперного театру у Львові (тепер - Львівський Національний Академічний театр опери та балету ім. Соломії Крушельницької). Сюжет опери присвячено життю карпатських верховинців. Партію Бронки виконувала Я. Королевич, Маринки - Г. Збоїнська-Рушковська, головну партію Янека композитор писав спеціально для О. Мишуги. «Він чудово, незабутньо виконав і цю партію. Про це заговорило все місто, слава розійшлася далеко за його межі. Через рік цю оперу поставили в Кракові, потім у Варшаві, Києві. Скрізь запрошували Олександра Мишугу виконувати партію Янека», - згадував А. Манастирський (Головащенко, 2004).

У Львівській опері протягом сезону 1900/1901 Олександр Мишуга проспівав одинадцять партій. Ф. Пайончковський у книзі «Львівський театр під дирекцією Тадеуша Павліковського. 1900-1906» про Мишугу писав: «В ліричних партіях був незрівняним, чарував пречудовим голосом і дикцією в ліричних і драматичних місцях Янека, захоплював чудовим співом у «Гальці», полонив пречудовим співом і теплотою щирих почуттів в «Манон», умів викликати захоплення в співаних і переспіваних аріях «Марти» (Головащенко, 2004).

Називаючи Мишугу «улюбленцем варшав'ян», 1901 року музичний критик «Театрального кур'єра» писав: «У Швейцарській долині (м. Варшава - Ц.С.) відбувся ювілейний концерт, в якому взяв участь знаменитий співак Олександр Мишуга. Улюблений співак був предметом сердечних овацій з боку спільноти, яка високо цінує талант артиста і завжди охоче поспішає на концерт» (КT, 1901). 
У жовтні 1901 року «з величезним успіхом» співак брав участь у концерті, організованому Музичним товариством у Лодзі, разом з Павелкем Коханським (Kronika, 1901: 34). Слід зазначити, що Олександр Мишуга впродовж багатьох років був членом Варшавського Музичного Товариства, про що свідчать звіти Товариства. А отже співак брав активну участь у проведенні концертних вечорів. У Варшавській філармонії, до прикладу, впродовж 1901-1910 років виступав 24 рази (РМ, 1912). У одному із таких концертів, що відбувся у листопаді 1901 року «перший тенор» виконував арії з «Янека» В.Желенського, серенади 3 «Мазепи», «Шумлять ялини» 3 «Гальки». У концерті також співали Соломія Крушельницька та Яніна Королевич (KT, 1901).

Дослідники творчості С.Крушельницької називають одним із останніх спільних виступів двох корифеїв 15 квітня 1903 року. У Львівському театрі за їх участі відбулась постановка опери «Манон» Ж. Масне (Медведик, Мисько-Пасічник, 2008).

Із листів до Варвари Літинської зі слів самого співака дізнаємося про успішні виступи на сцені Київської опери. У березні-квітні 1903 року Олександр Мишуга співав у багатьох постановках театру, серед яких: «Галька» Ст. Монюшка, «Фауст» Ш. Гуно, «Паяци» Р. Леонкавалло, «Травіата» Дж. Верді, «Лючія ді Ламмермур» Г. Доніцетті.

Київська публіка мала змогу бачити О. Мишугу 1905 р. (7 лютого) у ролі Йонтека. Постановка «Фауста» Ш. Гуно за його участі відбулась 10 лютого. В'ячеслав Мерзляков згадував Мишугу-Йонтека, який у згаданій постановці виступав зі своєю ученицею Яніною Королевич: «Це був винятково чудовий ансамбль двох талановитих артистів, володарів прекрасних голосів, співаків зі справжньою вокальною школою, які проникливо і переконливо, з великою, я б сказав, неповторною майстерністю відтворили на сцені живі образи героїв опери» (Головащенко, 2004).

У 1903 році, на початку 1904 року та 1905 року в Санкт-Петербурзі за участі О.Мишуги йшли спектаклі: «Галька» Ст. Монюшка, «Фауст» Ш. Гуно, «Паяци» Р. Леонкавалло, «Травіата» Дж. Верді, «Лючія ді Ламмермур» Г. Доніцетті, «Кармен» Ж. Бізе, «Гугеноти» Дж. Мейєрбера.

До слова, 1905 року О. Мишуга виконував польською мовою партію Йонтека, а виконавицею ролі Гальки була його учениця Ванда Рашковська. Газета «Русь» писала про «великий успіх», який вона мала у глядачів. Мишугу названо прекрасним співаком, «якого можна зарахувати до справді «нев'янучих». Незважаючи на те, що п. Мишуга уже багато років співає на сцені, він і донині збе- ріг свій голос і своє мистецтво. Ось що означає правильна, природна постановка голосу, відмінна школа і майстерне володіння диханням. Разом 3 тим в співі п. Мишуги багато смаку, дикція відзначається чудовою ясністю, а фразування - виразністю. На сцені він тримається вільно і вишукано. Словом, це справжній артист, якого завжди слухаєш і якого дивишся 3 повним задоволенням» (Головащенко, 2004).

У листопаді 1909 року Варшавська опера розпочала сезон «з «Гальки» 3 ідеальним Йонтеком п. Мишугою» (РМ Opera, 1909: 10-11). Закриття сезону також відбувалося за участі нашого славетного співака, який виступив у головній ролі «Фауста». Хоча поціновувачі оперного мистецтва вважали, що доречніше було би завершити сезон «Страшним двором» зі Стефаном-Мишугою (РМ, 1910: 1). Відома співачка Віра Люце пригадує, як у Варшаві говорили про Мишугу: «Коли співає Мишуга - змовкають солов"ї і буквально завмиpaє все, що $є$ живе в природі, настільки чарівний i проникливий тембр його голосу, його спів...» (Головащенко, 2004).

Починаючи з 1909 року у періодичних виданнях, зокрема, у Варшаві, все частіше з'являються повідомлення про виступи учениць класу професора Мишуги у концертах, в яких співає і сам професор. Критика вже більше акцентує увагу на досягненнях молодих співачок, нагороджуючи Мишугу щедрими компліментами щодо унікальності його системи вишколення голосів, судячи iз результатів, що їх демонструють молоді співачки - вихованки Музичної школи ВМТ.

20 лютого 1912 року у Варшаві відбувся концерт, присвячений творчості Ф. Шопена. Разом із знаменитим піаністом професором О. Міхаловським, хором «Лютня» під керівництвом П. Машинського, виступав і наш «заслужений артист-співак» О. Мишуга та інші відомі співаки. Критик А. Заблоцький у публікації про знаменну подію писав, що артисти «мали неабиякий успіх і були сердечно прийняті, тим більш заслуговували на це 3 огляду на благородну мету, якій присвятили свій талант і працю» (РМ, 1912: 5).

Милуватися співом «короля ліричних тенорів», як називав його сам Енріко Карузо, мала змогу й українська публіка. Олександр Пилипович брав активну участь у концертах, присвячених творчості Т. Шевченка, I. Франка, I. Котляревського. Їх поезія, покладена на музику українськими композиторами, у виконанні всесвітньовідомого співака набула глибокого змісту, справляючи неповторнояскраве враження на слухача. Він був неперевершеним виконавцем Лисенкових «Мені однаково», 
«Дівчинонько, рибалонько люба» (композитор присвятив цей романс О.Мишузі), «Помарніла наша доля» Анатоля Вахнянина, «Цвітка дрібная» Віктора Матюка, «Стоїть явір над водою» на музику Монюшкового «Козака».

Навесні та влітку 1914 року по всій Україні проводились урочистості, присвячені 100-літньому ювілею Тараса Шевченка. Відомий композитор, диригент, народний артист України Микола Колесса згадував один із концертів, який відбувся в березні у Львові. Тоді у виконанні О. Мишуги прозвучав твір «Цвітка дрібная» Віктора Матюка: «Він співав ії так проникливо і так натхненно, що вона запала мені в душу на ціле життя. Пригадую, що під час його виступу мій покійний батько Філарет Колесса нахилився до мене і шепнув на вухо: «Дивись добре, це наш славетний співак Мишуга» (Головащенко М., 2004). твори у його виконанні звучали якось особливо, по-новому, мали надзвичайну силу переконання, вселяючи віру у світле майбутнє для кожної людини, для держави, яку понад усе любив Олександр Пилипович Мишуга.

На жаль, маємо зовсім мало відомостей про концертно-виконавську діяльність українського тенора по від'їзді до Італії 1914 року. У спогадах Майї Чінберг, учениці маестро з 1915 року, чита$€ м 0$, що «прегарний голос широкого діапазону, не дивлячись на похилий вік маестро, ніби наперекір цьому зберігся таким, яким був колись». Співачка пригадує, що Олександр Мишуга «співав з молодечою силою і захопленням ліричні партії в операх «Лючія», «Ріголетто», «Травіата», а разом 3 тим, він, сповнений драматичної стихії та глибокого пафосу, міг відтворити Радамеса 3 «Аїди» чи Рауля 3 «Гугенотів». А при тім його тенор в подібних драматичних партіях звучав просто як баритон, - так маестро вмів володіти голосом і надавати йому такого забарвлення, якого вимагав характер даної ролі» (Головащенко, 2004).

За чотири місяці до смерті наш земляк співав у Стокгольмі разом з М. Чінберг у концерті в лікарні. За ii словами, «голос Мишуги, як і колись, був по-юнацькому свіжий, і він співав тоді з властивим йому запалом та виразністю». Це був останній концерт прославленого українського співака.

Ім'я Олександра Мишуги наприкінці XIX початку XX ст., завдяки його невтомній праці, невичерпній енергії, стало відомим далеко за межами нашої держави. Учениця маестро, вокальний педагог Варвара Долинська-Михалевич у записках про «чарівника співу» згадує випадок, який красномовно свідчить про безмежну любов Олександра Пилиповича до мистецтва, до співу, до сцени. «Якось я ішла 3 маестро по Володимирській гірці при чарівнім заході сонця. Зупинившись і дивлячись на цю картину, Мишуга вигукнув: «Дивись, як красиво, зовсім, як на сцені»!..» (Головащенко, 2004).

Йосип Дримайлик переказував висловлювання Мишуги щодо праці на українських сценах. Адже, окрім уривків з декількох українських опер, Мишуга не співав на великій сцені української оперної музики. Відповідаючи на запитання, чому ж він не повертається до театру, не співає частіше на українських сценах, співак порівнював себе 3 хіміком, який, не маючи умов для проведення дослідів, навряд чи зможе зробити відкриття у своїй галузі. Вважав, що більше користі приносить державі, заробляючи на чужих сценах, виділяючи великі кошти на потреби розвитку освіти, літератури, мистецтва України.

Висновки. Життєвим кредо «короля тенорів» була цілковита присвята себе мистецтву. За його словами, справжній співак повинен «любити мистецтво співу більше, ніж самого себе, і принести в жертву цьому мистецтву навіть свій егоїзм та особисте «я». Присвячувати себе мистецтву співу заради матеріальних вигод, тимчасової слави, похвал рецензентів і маси - це злочин перед собою і перед суспільством. Якщо любиш його лише заради краси, заради чистого ідеалу, який на крилах чарівних звуків уносить душу в світ мрій і почуттів, не затьмарених турботами повсякденного життя, тільки тоді варто ставати на важкий і складний, тернистий шлях співака. Хто перевірив себе і переконався, що не може жити спокійно без устремлінь до цього ідеалу, той сміливо може ставати на цей шлях...» (Головащенко, 2004: 287).

Олександр Філіппі-Мишуга був співаком окресленого репертуару, з виразно зазначеними емоційно-образними пріоритетами, які випливали почасти з природи його голосу, почасти - 3 індивідуально-психологічних засад, а також і з свідомо обраних і сформованих естетичних переконань. Вся критика згідно відзначає кілька найважливіших його переваг як співака-артиста: чутливість, тонку тактовну експресію, гармонійність і природність виконання, здатність відчувати ансамбль. Багата панорама музичної спадщини Олександра Мишуги включає в себе особливі обставини творчої кар'єри видатного українського співака, осягнення ним вершин вокальної майстерності здебільшого всупереч зовнішнім предиспозиціям, утримання прекрасної співочої $\mathrm{i}$ артистичної форми до поважного віку, рівновагу і досконалу взаємодоповнюваність різних видів музично-професійної діяльності - виконавської, педагогічної, науково-дидактичної і суспільно-харитативної. 


\section{СПИСОК ВИКОРИСТАНИХ ДЖЕРЕЛ}

1. Варварцев М. Олександр Мишуга: перші кроки на ниві італійської культури. Міжнародні зв'язки Украӥни: наукові пошуки і знахідки, 1992. 2. С. 37-42.

2. Головащенко М. (Авт.-упоряд.). Олександр Мишуга - король тенорів. Київ: Музична Україна. 2004.610 с.

3. Головащенко М.. Пісень дивних чародій. Жовтень, 1971. 3. С. 116-127.

4. Кротевич Е. Спогади про людей, факти, подіі. Київ: Молодь. 1963. С. 137-143.

5. Медведик П., Мисько-Пасічник Р. (Упоряд.). Соломія Крушельницька. Шляхами тріумфів : статті та матеріали. Т.: Джура. 2008. 392 с.

6. Новинки. Мышуга-Филиппи, колись бурсакъ Ставропигіи... Діло. 1885. Січень 26. с. 3.

7. Новинки. Филипъ Мышуга закончивъ недавно свои выступы... Діло. 1885. Березень 12 (24). с. 3.

8. Паламарчук О. Музичні вистави львівських театрів (1776-2001). Львів: Ф-т культури і мистецтв ЛНУ ім. І. Франка. 2007. 448 с.

9. Центральний державний історичний архів України, м. Львів. Ф. 688 Гнат Хоткевич. 1893-1899 рр. Оп. 1 Спр. 183. Про концерти українського співака О. Мишуги в Галичині та за кордоном. 3 матеріалів Гната Хоткевича до праці по історії Українського театру. Т. 3 (1893-1899 рр.). 54 арк.

10. Bylicki F. Opera. Czas. 1895. 137. S. 3.

11. Dzieje teatru polskiego. Teatr polski w latach 1890-1918: Zabór austriacki i pruski. Warszawa: Państwowe Wydawnictwo Naukowe. 1987. $495 \mathrm{~s}$.

12. Dzieje teatru polskiego. Teatr polski w latach 1890-1918: Zabór rosyjski. Warszawa: Państwowe Wydawnictwo Naukowe. 1988. $861 \mathrm{~s}$.

13. Kronika. Kurjer Teatralny. TygodnikArtystycznypoświęcony sprawom teatru imuzyki. Warszawa. 1901.34. S. 558-559.

14. Reiss J. W. Polscy śpiewacy i polskie śpiewaczki. Warszawa: Czytelnik. 1948. 28 s.

15. Śledziński S. (Red. nacz.). Stownik Biograficzny Teatru Polskiego. 1765-1965. [Na podstawie materiałów Stanisława Dadrowskiego]. Warszawa: PWN. 1973. 906 s.

16. Teatr i muzyka. Lunatyczka. Echo Muzyczne, Teatralne i Artystyczne. Warszawa. 1890. 330. S. 51.

17. Wypych-Gawrońska A. Lwowski teatr operowy i operetkowy w latach 1872-1918. Krakớw. 1999. $407 \mathrm{~s}$.

18. Z muzyki. Filharmonia. Dolina Szwajcarska. Kurjer Teatralny. Tygodnik Artystyczny poświęcony sprawom teatru $i$ muzyki. Warszawa. 1901. 44. S. 708-709.

\section{REFERENCES}

1. Centraljnyj derzhavnyj istorychnyj arkhiv Ukrajiny, m. Ljviv. Pro koncerty ukrajinsjkogho spivaka O. Myshughy v Ghalychyni ta za kordonom. [About the concerts of the Ukrainian singer O. Myshuga in Galicia and abroad]. F. 688 Ghnat Khotkevych. 1893-1899 rr. Op. 1 Spr. 183. [in Ukrainian].

2. Gholovashhenko, M. (1971). Pisenj dyvnykh charodij. [Songs of strange wizards]. Zhovtenj. 3. S. $116-127$. [in Ukrainian].

3. Gholovashhenko, M. (Avt.-uporjad.). (2004). Oleksandr Myshugha - korolj tenoriv [Alexander Myshuga is the king of tenors]. Kyjiv: Muzychna Ukrajina.

4. Krotevich, E. (1963). Spogadi pro lyudej, fakti, podiyi [Memories of people, facts, events.]. Kiyiv: Molod. [in Ukrainian].

5. Medvedyk, P., Mysjko-Pasichnyk, R. (Uporjad.). (2008). Solomija Krusheljnycjka. Shljakhamy triumfiv : statti ta materialy [Solomiya Krushelnytska. Ways of triumphs: articles and materials.]. T.: Dzhura. [in Ukrainian].

6. Novinki. Myshuga-Filippi, kolis bursak Stavropigii... (1885, Sichen 26). [Myshuga-Filippi, once a bursak of Stavropigii ...]. Dilo. S. 3. [in Ukrainian].

7. Novinki. P. Filip Myshuga zakonchiv nedavno svoi vystupy... (1885, Berezen 12 (24)). [Filip Myshuga recently finished his performances ....] Dilo. S. 3. [in Ukrainian].

8. Palamarchuk, O. (2007). Muzychni vystavy ljvivsjkykh teatriv (1776-2001.) [Musical performances of Lviv theaters (1776-2001)]. Ljviv: F-t kuljtury i mystectv LNU im. I. Franka. [in Ukrainian].

9. Varvarcev, M. (1992). Oleksandr Myshugha: pershi kroky na nyvi italijsjkoji kuljtury [Alexander Myshuga: the first steps in the field of Italian culture]. Mizhnarodni zv'jazky Ukrajiny: naukovi poshuky i znakhidky, 2. S. 37-42.

10. Bylicki, F. (1895) Opera [Opera]. Czas, 137. S. 3. [in Ukrainian].

11. Dzieje teatru polskiego. Teatr polski w latach 1890-1918: Zabór austriacki i pruski. (1987). Warszawa: Państwowe Wydawnictwo Naukowe. 495 s. [in Polish].

12. Dzieje teatru polskiego. Teatr polski w latach 1890-1918: Zabór rosyjski. (1988) [History of Polish theater. Polish theater in the years 1890-1918]. Warszawa: Państwowe Wydawnictwo Naukowe. 861 s. [in Polish].

13. Kronika (1901) [Chronicle]. Kurjer Teatralny. Tygodnik Artystyczny poświęcony sprawom teatru i muzyki. 34. Warszawa. S. 558-559. [in Polish].

14. Reiss, J. W. (1948). Polscy śpiewacy i polskie śpiewaczki [Polish singers and Polish singers]. Warszawa: Czytelnik. 28 s. [in Polish].

15. Śledziński, S. (Red. nacz.). (1973). Stownik Biograficzny Teatru Polskiego. 1765-1965. [Biographical Dictionary of the Polish Theater.]. Warszawa: PWN. 906 s. [in Polish].

16. Teatr i muzyka. Lunatyczka (1890) [Theater and music. Sleepwalker]. Echo Muzyczne, Teatralne i Artystyczne. 330. Warszawa, s. 51. [in Polish].

17. Wypych-Gawrońska, A. (1999). Lwowski teatr operowy i operetkowy w latach 1872-1918. [Lviv opera and operetta theater in the years 1872-1918] Krakớw. 407 s. [in Polish].

18. Z muzyki. Filharmonia. Dolina Szwajcarska (1901) [From music. Philharmonic. Swiss Valley]. Kurjer Teatralny. Tygodnik Artystyczny poświęcony sprawom teatru i muzyki. 44. Warszawa. S. 708-709. [in Polish]. 